\title{
Antidiabetic Medicinal Plants Used by the Basotho Tribe of Eastern Free State: A Review
}

\author{
Fatai Oladunni Balogun, Natu Thomas Tshabalala, and Anofi Omotayo Tom Ashafa \\ Phytomedicine and Phytopharmacology Research Group, Department of Plant Sciences, University of the Free State, \\ Qwaqwa Campus, Private Bag X 13, Phuthaditjhaba 9866, South Africa \\ Correspondence should be addressed to Anofi Omotayo Tom Ashafa; ashafaaot@ufs.ac.za
}

Received 31 January 2016; Revised 9 March 2016; Accepted 31 March 2016

Academic Editor: Mohammad A. Kamal

Copyright (c) 2016 Fatai Oladunni Balogun et al. This is an open access article distributed under the Creative Commons Attribution License, which permits unrestricted use, distribution, and reproduction in any medium, provided the original work is properly cited.

\begin{abstract}
Diabetes mellitus (DM) belongs to the group of five leading important diseases causing death globally and remains a major health problem in Africa. A number of factors such as poverty, poor eating habit, and hormonal imbalance are responsible for the occurrence of the disease. It poses a major health challenge in Africa continent today and the prevalence continues to increase at an alarming rate. Various treatment options particularly the usage of herbs have been effective against diabetes because they have no adverse effects. Interestingly, South Africa, especially the Basotho tribe, is blessed with numerous medicinal plants whose usage in the treatment of DM has been effective since the conventional drugs are expensive and often unaffordable. The present study attempted to update the various scientific evidence on the twenty-three (23) plants originating from different parts of the world but widely used by the Sotho people in the management of DM. Asteraceae topped the list of sixteen (16) plant families and remained the most investigated according to this review. Although limited information was obtained on the antidiabetic activities of these plants, it is however anticipated that government parastatals and scientific communities will pay more attention to these plants in future research.
\end{abstract}

\section{Introduction}

Diabetes mellitus (DM) is an endocrine disorder marked by abnormalities in lipid, carbohydrates, and protein metabolism. It does not only cause hyperglycemia but result in numerous complications which are grouped as acute, subacute, or chronic; these include but are not limited to retinopathy, neuropathy, nephropathy, cardiovascular disorders, hypoglycemia, diabetic ketoacidosis, hyperosmolar nonketotic syndrome, polydipsia, frequent urination, lack of vigour, ocular impairment, weight loss, and excessive eating (polyphagia) $[1,2]$.

Diabetes mellitus (DM) may be classified based on the etiology and clinical symptoms as type 1 (insulin dependent diabetes mellitus, IDDM) and type 2 (non-insulin dependent diabetes mellitus, NIDDM). It is a typical and very predominant disease which troubles people of different classes and races worldwide [3]. Report from International Diabetes Federation (IDF) revealed that the menace presently affects well over 366 million (M) people globally and that, by 2030 , the figure will be reaching $552 \mathrm{M}$ [4]. It is estimated that
Nigeria (3.2 M), South Africa (2 M), Kenya (over $0.7 \mathrm{M}$ ), and Cameroun (over $0.5 \mathrm{M}$ ) top the list of countries with the prevalence of the disease in each subregion of Africa [5]. DM is also considered a vital cause of disability and hospitalization as it results in significant financial burden [6].

Due to the inherent side effects such as hypoglycemia, weight increase, gastrointestinal (GIT) disturbances, nausea, and diarrhoea [7] of common oral hypoglycemic synthetic drugs like sulphonylureas (glibenclamide, e.g., Daonil), biguanides (metformin, e.g., Glucophage), and glucosidase inhibitors like Acarbose, researchers are now intensifying efforts in alternative and complementary medicines to proffer lasting solution or at least stem the burden of this menace [8]. This is partly because herbal remedies are more efficient and have little or no adverse effects and could also be due to the fact that they form a vital component of the health care delivery system in most African nations [9]. World Health Organization (WHO) in one of their submissions advocated the evaluation of medicinal plants (MP) based on their efficacy, low cost, and possession of little or no adverse effects [10]. Similarly, WHO in one of their technical reports [11] 


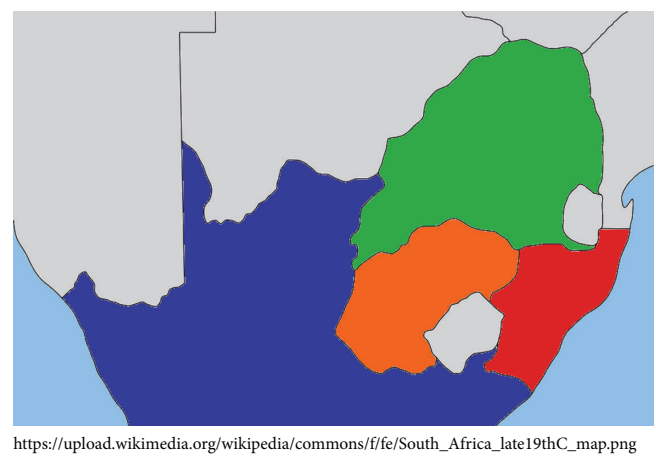

FIgURE 1: Map of South Africa showing the Basotho region (highlighted in orange).

maintained that 4/5th of the citizens in African countries rely on folk medicines particularly herbal remedy for their primary health care requirements $[12,13]$. This could be ascribed to the efficacy and availabilities of these plants because they account for $25 \%$ of higher plants in the world comprising 5400 with more than 16300 medicinal uses [14]. South Africa (SA) accounts for 9\% (about 30000 species) of higher plants in the world [15]. It is therefore not amazing that over 3500 species of these plants are employed by over 20000 indigenous healers [16]. Interestingly, about $80 \%$ of South Africans use plants for therapeutic purposes [17] mainly because the cost of buying orthodox medicine or conventional treatment continues to increase, thus making affordability impossible.

Herbal drugs with antidiabetic activity are known for their therapeutic potentials within the traditional healthcare system, but despite their pronounced folkloric activity, they have not been commercially formulated as modern medicines. This is despite the fact that their therapeutic properties have been reported to serve as a potential source of hypoglycemic drugs and many of these compounds derived from plants are used in the management of DM. This is confirmed by numerous ethnobotanical surveys conducted on medicinal herbs employed in the control of DM from divergent regions, communities, and tribes within the African subregion [18-27].

Basotho (South Sotho) tribes are the largest population of blacks within SA and they are concentrated in Free State, Gauteng, and Eastern Cape (Figure 1) Provinces. It is worth mentioning that their knowledge and usage of numerous MP in the treatment of various disorders such as DM and hypertension cannot be overemphasized. Tshabalala and Ashafa [28] in the past conducted an ethnobotanical overview of plants utilized for diabetes control by the Basotho people and identified twenty-three (23) plants with such potentials. In this paper, we conducted a comprehensive review of these plants with a view to helping researchers and government agencies to avert the probable extinction of these plants. This review is also intended to serve as a guide for possible future research on the scientifically unproven plants.

\section{Methodology}

Literature used for this review was obtained through searching the individual botanical names of the plants on Google
Scholar. Informative articles used in this study were sourced from scientific databases such as Science Direct, PubMed, and Medicine. The articles mostly cover the period between 2000 and 2015. One hundred and sixteen (116) journals were retrieved, although emphasis was placed on the hypoglycemic and/or hyperglycemic and antihyperlipidemic activities of the plants when keywords such as MP and hypoglycemic were typed in. Various other in vitro and in vivo pharmacological activities of these plants (Tables 1 and 2) were sourced from 79 of the peer-reviewed articles.

\section{Basotho Ethnobotanically Reported Plants with Antidiabetic Potentials}

3.1. Eriocephalus punctulatus. Eriocephalus punctulatus is a flowering plant belonging to the Asteraceae (daisy) genus family with over 35 species. It is commonly called wilde roosmaryn, Kapokbos (meaning snowbush in Afrikaans), and wild rosemary (Eng.) and it is widely distributed in SA (in mountain areas of Free State and Western Cape Provinces) and Namibia [29, 30]. Traditionally, the plant is used as diaphoretic and diuretic agents [31] and for the treatment of cold [32], DM, and so forth. E. punctulatus contains essential oil called Cape chamomile which comprises over 50 aliphatic esters with 2-methyl butyl-2-methyl propanoate (21.2\%), 7methylbutyl-2-methyl butanoate (5.6\%), 2-methylpropyl-2methyl propanoate $(5.3 \%), 7$-methyl-2-octyl acetate $(4.5 \%)$, linalyl acetate $(4.4 \%)$, and $\alpha$-pinene $(1.9 \%)$ as main compounds [29] reported to be of use in cosmetic toiletries and aromatherapy [29]. The anti-inflammatory, antiallergic, antidepressant, and antiseptic properties of E. tenuifolius essential oil, a related species of E. punctulatus, have been reported [33]. Njenga et al. [34] reported the antimicrobial activity of E. punctulatus with other species of Eriocephalus and 113 essential oils. Antioxidant and anti-inflammatory properties were also reported [35] however; a report from chemotaxonomic evidence suggests that Cape chamomile oil is a product of E. tenuifolius and not E. punctulatus [33] and to date no scientific evidence of its antidiabetic potentials has been reported.

3.2. Hypoxis hemerocallidea. Hypoxis hemerocallidea formerly referred to as $H$. rooperi (African potato) according to Laporta et al. [36] belongs to the Hypoxidaceae (star lily) family. The locally called star flower and yellow star (Eng.); sterblom and gifbol (Afr.); moli kharatsa and Lotsane (South Sotho); or Inkomfe (Zulu) is widely distributed within SA virtually in all the provinces and can be found in other African countries such as Botswana, Lesotho, and Swaziland. There are over 76 species of the genus Hypoxis in Africa, 40 of which are found in SA while 16 others are endemic to SA. Traditionally, various parts of the plant are used in the treatment of various diseases such as dizziness, burns, wounds, anxiety, depression or insanity, DM, cancer, polyarthritis, hypertension, and asthma $[37,38]$. The formulated and marketed products of the species have been reported to ameliorate benign prostrate hypertrophy $(\mathrm{BPH})$, urinary infections, and immune modulations [39]. Activities of this 


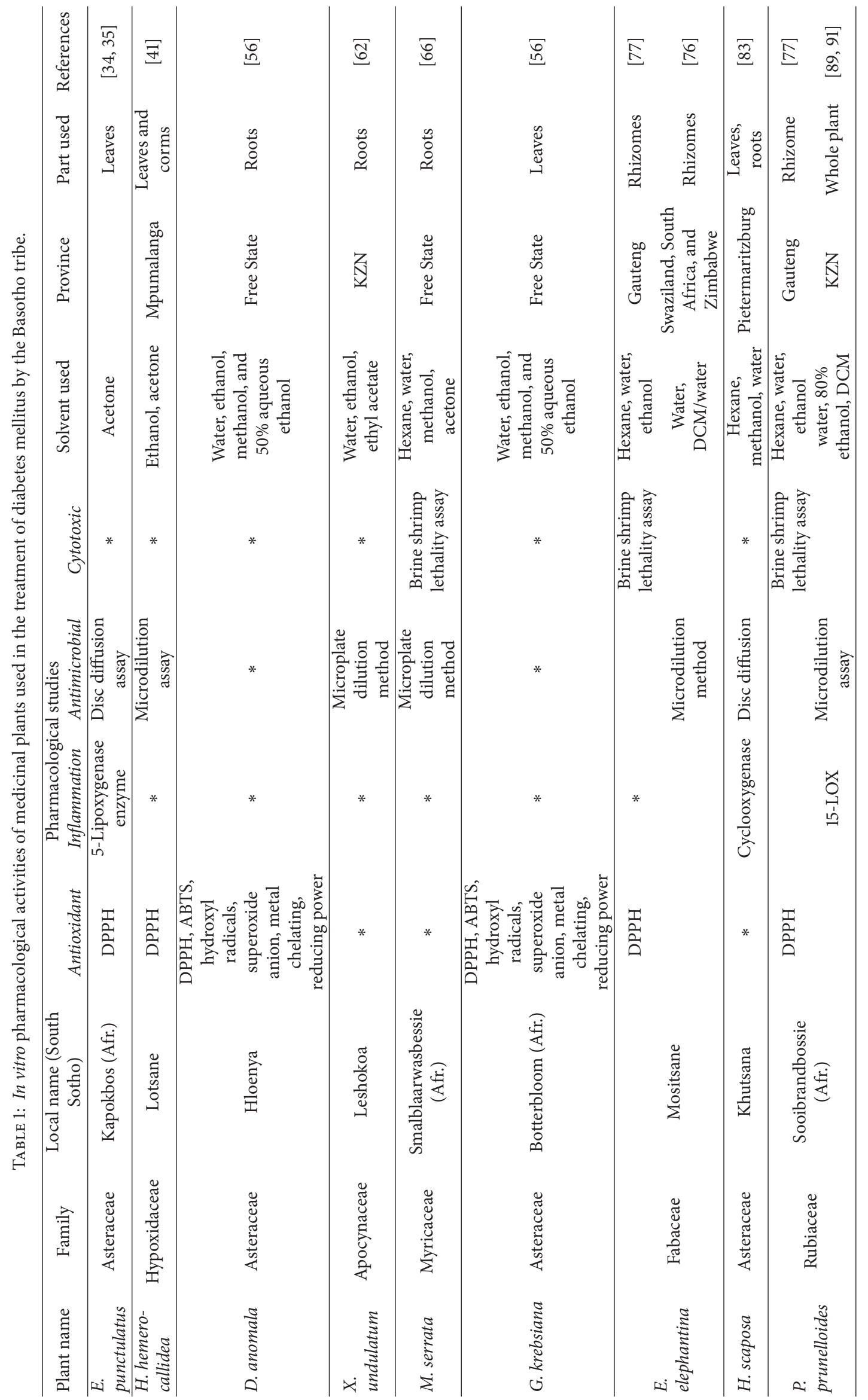




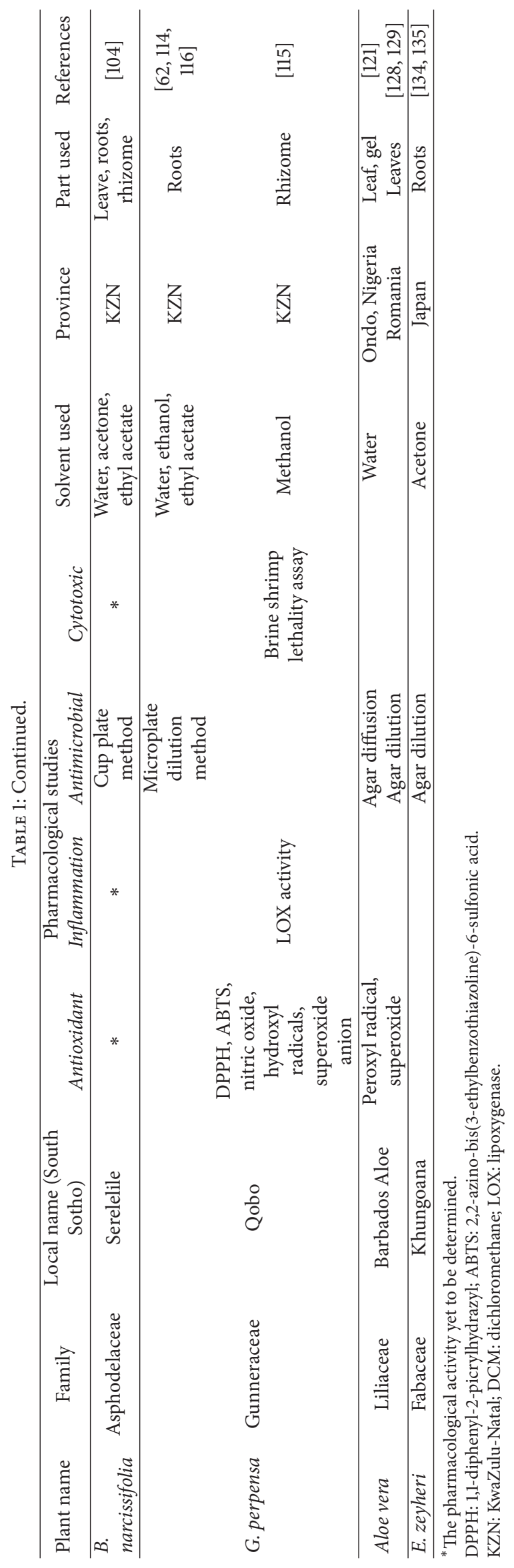




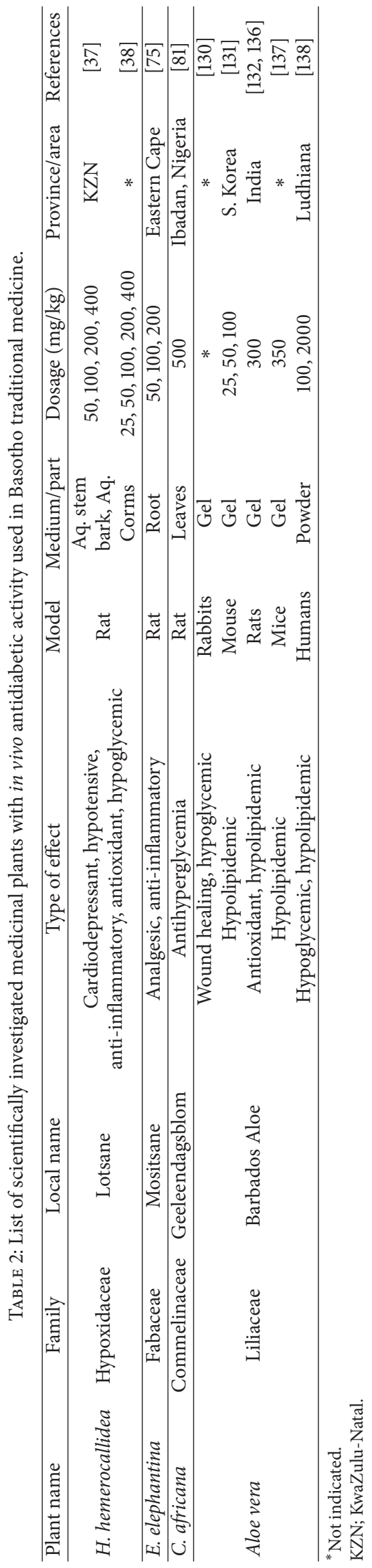


plant are attributed to its main bioactive compounds, hypoxoside and its aglycone derivative, rooperol [40]. Katerere and Eloff [41] maintained that the leaves and corms of the plant possess antibacterial and antioxidant activities while the anticonvulsant activity was recently reported by Liu et al. [42]. The cardiovascular activity of $H$. hemerocallidea was reported in experimental animal models [38], antidiarrhoea activity was reported in rodents [43], and the uterolytic effect was found in rats and guinea pigs [44]. The antinociceptive activity (studied in mice) and the anti-inflammatory and antidiabetic activities (rats) have been reported when aqueous extract $(50-800 \mathrm{mg} / \mathrm{kg})$ of this plant was administered to rodents induced with a rat hind paw oedema $(0.5 \mathrm{mg} / \mathrm{kg})$ and streptozotocin $(90 \mathrm{mg} / \mathrm{kg})$, respectively (Table 2$)$. The herb was able to bring about a significant reduction in the fresh egg albumin-induced acute inflammation of the rat hind paw and blood glucose concentrations in these animals [37]. Several other reports of these activities had also been detailed by several authors [40, 45-47].

3.3. Dicoma anomala. Dicoma anomala belongs to the Asteraceae family. The plant commonly called fever bush and stomach bush (Eng.); maagbitterwortel, kalwerbossie, koorsbossie, gryshout, and maagbossie (Afr.); Hloenya and Mohasetse (South Sotho); Inyongana (Swazi, Xhosa); or Isihlabamakhondlwane and Umuna (Zulu) is a herbaceous plant that grows in grassland, stony places, hillsides, flat grasslands, and savannah areas within an altitude that ranges from 165 to $2075 \mathrm{~m}$ [48]. D. anomala is widely distributed within SA in places such as Limpopo, North West, Gauteng, Mpumalanga, Free State, Northern Cape, and KwaZulu-Natal [49] and over 16 species of the genus Dicoma exist in SA with D. tomentosa and D. anomala being the most distributed species in Africa. Traditionally, the plant is used in the treatment of coughs and colds, fevers, ulcers, dermatosis, venereal diseases, labour pains, dysentery, intestinal parasites, stomach pains, toothache, and internal worms which are linked to versed majority of pharmacological activities such as antihelminthic, antispasmodic, analgesic, wound healing, anti-inflammatory, and antimicrobial activities [50-52]. Dicoma tomentosa from the same genus was reported to possess antiplasmodial activity [53] while the in vitro inhibitory potentials of $D$. anomala against cytochrome p450 enzymes and p-glycoprotein were also reported [54]. The antiplasmodial activity of D. anomala in vitro [55] as well as the in vitro antioxidant activity is recently reported (Table 1) by Balogun and Ashafa [56] but unfortunately, report on the in vivo antidiabetic activity of the plant is still awaited in the scientific world.

3.4. Xysmalobium undulatum. Xysmalobium undulatum is a member of the Apocynaceae family. The plant is commonly called milk bush, milkwort, Uzura, wild cotton, and waveleaved Xysmalobium (Eng.); bitterhout, bitterwortel, bitterhoutwortel, and melkbos (Afr.); Leshokoa and Poho-tsehla (South Sotho); iyeza elimhlophe, Nwachaba, and Ishongwane (Xhosa); or Ishongwane, Ishongwe, and Ishinga (Zulu). The plant is widely distributed in all provinces within SA as well as Namibia, Botswana, Lesotho, and Swaziland. There are over forty (40) species of the genus Xysmalobium in the world and 24 species of these are found in SA. Locally, the usage of the plant is in the treatment of stomach cramps, diarrhoea, colic, afterbirth cramps, headache, wounds, and abscesses $[48,50,57,58]$. The main compounds as elucidated by Ghorbani et al. [59] are uzarin and xysmalorin with few quantities of allouzarin and alloxysmalorin. Steenkamp et al. [60] reported the in vitro antioxidant activity and selective serotonin reuptake inhibitors (SSRI) antidepression activity of the plant reported by Pedersen et al. [61]. Antibacterial and antifungal properties [62], antiplasmodial and central nervous system (CNS) activity [63], antidiarrhoeal activity [64], and inhibition of uptake of serotonin [16] are reported. Still, no scientific work on the antidiabetic activity of the plant was found in the literature.

3.5. Morella serrata. Morella serrata belongs to the Myricaceae family and it is locally called Smalblaarwasbessie and Berg-wasbessie (Afr.); lance-leaved strawberry, waxberry, and mountain waxberry (Eng.); Isibhara, Umakhuthula, and Umaluleka (Xhosa); or Iyethi, Ulethi, Umakhuthula, and Umlulama (Zulu). M. serrata grows along streams on grassy hillsides as well as on forest fringes. They are widely distributed within SA virtually in all the provinces while they are also occurring in Swaziland, Zimbabwe, and northern Botswana. Traditionally, the plant is used to cure headaches and tuberculosis [65] and for the management of DM. The antimicrobial and antitumor activity of the plant have been reported [66]; however, it is worth reporting that the pharmacological evidence of its antidiabetic efficacy still remains unknown.

3.6. Gazania krebsiana. Gazania krebsiana belongs to the family Asteraceae and it is locally referred to as terracotta Gazania meaning "beautiful flower" (Eng.); gousblom and botterbloom (meaning) butterflower (Afr.). There are over nineteen (19) species of the genus Gazania in Africa and most of these are predominantly found in SA. The plant is distributed in all the provinces of SA from Namaqualand in the west to the Eastern Cape and KwaZulu-Natal (KZN) in the east, through Free State in the north and Gauteng. The plant is used in the management of DM traditionally among the Basotho tribe and recently Balogun and Ashafa [56] reported the antioxidant activity of the plant in in vitro study (Table 1) but in our view, there is no scientific evidence to support its antidiabetic efficacy to date.

3.7. Elephantorrhiza elephantina. Elephantorrhiza elephantina is a member of Fabaceae or Leguminosae family. The plant is commonly called eland's bean, eland's wattle, and elephant's root (Eng.); baswortel, elands-boontjie, leerbossie, looiersboontjie, and olifantswortel (Afr.); Mupangara (Shona); Mositsane (South Sotho, Tswana); or Intolwane (Xhosa, Zulu). There are over nine (9) species of the genus Elephantorrhiza and the species elephantina is the most widely spread. It can be found in southern Angola, Namibia, Botswana, Zimbabwe, and Mozambique and in most provinces within SA. Traditionally, the plant is used to treat diarrhoea, dysentery, stomach disorders, haemorrhoids, peptic 
ulcer, skin diseases, and acne [58, 67-70]. The anthelmintic activity in vitro and in vivo was reported by Maphosa et al. [71]. Equally, the antiprotozoal activity has been reported $[72,73]$. Mathabe et al. [74] also reported the antibacterial activity while the anti-inflammatory, antinociceptive in vivo [75], antimicrobial [76], antioxidant, cytotoxic [77], and immune enhancing as well as anti-HIV [78] activities were similarly reported (Table 1). Despite these various pharmacological reports, there has not been any scientific literature that supports its antidiabetic properties.

3.8. Hermannia pinnata. Hermannia pinnata belongs to the family of Malvaceae (Mallow) and is commonly called orange Hermannia or doll's rose (Eng.); Kwasblaar and Kruip Poprosie (Afr.). There are over 180 species of the genus Hermannia in SA; 162 species of these are widely spread across the country. Traditionally, the Sotho tribe used the plant in the management of DM but the scientific efficacy has not been ascertained.

3.9. Commelina africana. Commelina africana, a member of the Commelinaceae family, is commonly called yellow Commelina (Eng.); geeleendagsblom (Afr.). Sixteen (16) of the over 170 species of the genus Commelina in the world are found in SA. They are mostly distributed in Africa (e.g., Madagascar) as well as other places of the world such as Arabian Peninsula where there are forest, savannah, and grassland. Traditionally, the plant is useful in the treatment of venereal diseases and as medicine for women suffering from menstrual pain and infertility $[31,79,80]$. The hypoglycemic effect of the plant extract had been reported in alloxan $(125 \mathrm{mg} / \mathrm{kg})$ induced diabetic rats when aqueous leaves extracts of the plant brought down the increased glucose level of the animals (Table 2). This reduction by the plant not only was attributed to its inhibitory effect on glucose absorption but could probably be due to other mechanisms such as direct stimulation of glycolysis in peripheral tissues, facilitation of glucose entry into peripheral cells, reduced hepatic gluconeogenesis, and reduction of plasma glucagon levels [81].

3.10. Haplocarpha scaposa. Haplocarpha scaposa belongs to the family Asteraceae and is commonly called false gerbera (Eng.); melktou (Afr.); Khutsana (South Sotho); or Isikhali (Xhosa). Ten (10) species of the genus Haplocarpha existed and five (5) of them occur in central Africa. H. scaposa is endemic to Africa and is widely distributed in Mpumalanga, Free State, Eastern Cape within SA, Swaziland, and some part of eastern Africa [82]. Traditionally, the plant is used to reduce menstrual pain and in the management of DM [82]. $H$. scaposa has been reported to exhibit anti-inflammatory activity [83]; however, it is noteworthy to report that research on the antidiabetic activity of the plant has not been validated to date.

3.11. Helichrysum aureum. The plant belongs to the Asteraceae family and is locally called Leabane (South Sotho). According to Flora of Zimbabwe [84], there are over 600 species of the genus Helichrysum in the world; about 244 to 250 of these species are found in Africa, particularly SA. The plant is found in submontane grassland and miombo woodland areas with a wide distribution in Mozambique, Zimbabwe, Lesotho, Swaziland, and SA (precisely Eastern Cape and Free State). The areas of the world where Helichrysum species predominates include southern Europe, southwest Asia, southern India, Sri Lanka, and Australia [85]. The antimicrobial and cytotoxic activity of the plant had been reported [86].

3.12. Empodium plicatum. Empodium plicatum belongs to the Hypoxidaceae family and is locally called golden star (Eng.); Ploegtydblommetjie (Afr.). E. plicatum is endemic to SA and widely distributed in Northern and Western Cape. Traditionally, Basotho people use the plant to manage DM although information from the literature at the time of compiling this review reveals no scientific report on the pharmacological activity of the plant.

3.13. Mimulus gracilis. The plant belongs to the family of Scrophulariaceae and is locally called Sehlapetsu (South Sotho). However, the plant is not endemic to SA but is widely distributed in Eastern Cape, Free State, KZN, Limpopo, Mpumalanga, Northern Cape, and North West Provinces. It is also reported to be abundant in Angola, Botswana, Namibia, Nigeria, Sudan, Kenya, Tanzania, Ethiopia, Malawi, Mozambique, Zambia, Zimbabwe, Lesotho, Yemen, India, China, and Australia. Traditionally, the plant is used to treat $\mathrm{DM}$ by Basotho people; there is urgent need to determine the antidiabetic activity of the plant for the treatment of DM.

3.14. Pentanisia prunelloides. Pentanisia prunelloides belongs to the Rubiaceae family. The plant is locally called wild verbena and broad-leaved Pentanisia (Eng.); Sooibrandbossie (Afr.); or Icimamlilo (Zulu). Three (3) of the 15 species of the genus Pentanisia are found in SA. Traditionally, various uses of the plant include diarrhoea, dysentery, rheumatism, heartburn, vomiting, fever, toothache, tuberculosis, snakebite, haemorrhoids, burns, and swellings. The in vitro anti-inflammatory and antioxidant activity of the plant have been reported [87]. Mpofu et al. [77] established the antibacterial, cytotoxic, and antioxidant activities while the antiinflammatory, antimycobacterial, antimicrobial, nongenotoxic [88-90], and antioxidant and anti-inflammatory [91] activities in vitro had also been reported (Table 1). It is interesting to note that, despite the various in vitro activities, there is a dearth of information on the antidiabetic activities of the plant.

3.15. Cannabis sativa. Cannabis sativa belongs to the Cannabaceae family. The local names include marijuana (Eng.); dagga (Afr.); Umya (Xhosa); Matekwane or Patse (Northern Sotho); or Nsangu (Zulu). The plant originated from Asia but is presently being cultivated in many countries of the world though naturalized in SA. Three varieties of cannabis are recognized, namely, sativa which is commonly referred to as hemp, cultivated for psychoactive cannabinoids, durable fibre, and nutritious seed [92], while the other varieties are 
indica and spontanea. Cannabis is widely distributed in SA and sativa variety predominates in Botswana, Limpopo, North West, Gauteng, Mpumalanga, KZN, Western Cape, Eastern Cape, Lesotho while indica variety can also be found in Mpumalanga, whereas spontanea variety is in Northern Cape. Traditionally, the plant is used as a cure for asthma, bronchitis, headache, flu, epilepsy, cough, and pains. The crude drug and the pure chemical derivatives are used in modern day medicine in the treatment of a migraine, epilepsy, malaria, glaucoma, nausea, acquired immune deficiency syndrome (AIDS), appetite induction for cancer patients, and muscular spasm suppression in multiple sclerosis [93]. Its main active compound is called $\Delta^{9}$-tetrahydrocannabinol $[94,95]$. The antipsychotic activity of the plant has been investigated and reported in rodents and humans [9597]. The neuroprotective, antioxidative, and antiapoptotic activity [98] and the antibacterial activity of cannabinoids [99] and anticonvulsive, anti-inflammatory, and analgesic activity of $\Delta^{9}$-tetrahydrocannabinol have been reported [100102], but till date, the scientific validation of the antidiabetic activity has not been reported.

3.16. Bulbine narcissifolia. Bulbine narcissifolia is a member of the Asphodelaceae family. The local names include strapleafed bulbine and snake flower (Eng.); lintblaar bulbine, geelslangkop, and wildekopieva (Afr.); Khomo-ea-balisa and Serelelile (South Sotho). It has been reported that different names of the plant are adopted based on the appearance and due to the wide use of the genus by all stakeholders or tribes within SA $[14,93]$. There are 73 species of the genus Bulbine; 67 are predominant in Africa while 6 species are found in Australia. The most common species are B. frutescens, $B$. abyssinica, B. latifolia, B. natalensis, and B. narcissifolia. The latter species is widely distributed in Western Cape, Eastern Cape, Free State, KZN, North West, Gauteng, and Limpopo within SA and in Lesotho, Botswana, and Ethiopia. Traditionally, the plant is of utmost importance in wound healing and as a mild purgative [103] and in vomiting, diarrhoea, urinary infections, DM, rheumatism, and bloodrelated problems. The antibacterial [104] and anticancer and antimicrobial [105] activities of the plant have been reported in vitro but till date, there has not been any scientific evidence of antidiabetic properties.

3.17. Rumex lanceolatus. Rumex lanceolatus belongs to the Polygonaceae family; the common names include the small dock, smooth dock, and common dock (Eng.); Gladdetongblaar (Afr.); Idolo Lenkonyane (Zulu); Idolonyana (Xhosa); Khamane, Kxamane, and Molokoli (South Sotho). The plant is not endemic to SA but is widely distributed within SA in Eastern, Western, and Northern Cape, Free Sate, Gauteng, KZN, Limpopo, Mpumalanga, and North West. Ethnobotanically, the root and rather the leaves are used as medicine [106]. The plant serves as a cure for infertility, intestinal parasites [31], internal bleeding [107], and DM. The nonmutagenic activity [108] has been reported while the presence of chrysophanol and related glycosides has been attributed to its laxative activity [107]; however, there has not been any scientific fact about its antidiabetic efficacy in the literature.

3.18. Gunnera perpensa. Gunnera perpensa is one of the members of Gunneraceae family. It is locally referred to as river pumpkin and wild rhubarb (Eng.); rivierpampoen and wilde ramenas (Afr.); Qobo (Sotho); Uqobho (Swati); rambola-vhadzimu and shambola-vhadzimu (Venda); Iphuzi lomlambo and Ighobo (Xhosa); Ugobhe and Ugobho (Zulu). Fifty (50) species of the genus Gunnera existed and only perpensa are found in Africa. Gunnera are naturally occurring in central and southern Africa, Madagascar, New Zealand, Tasmania, Indonesia, Philippines, Hawaii, Mexico, and central and southern America. G. perpensa is widespread in Sudan, Ethiopia, Zaire, Rwanda, Uganda, Kenya, Zimbabwe, SA (Western and Northern Cape), Swaziland, Lesotho, Namibia, and Botswana [109]. Traditionally, the plant is used to remove placenta in newborn and to relieve menstrual pain $[106,110-$ 112]. The toxic effect of the plant was investigated in rats when aqueous extract of the plant at different concentrations (50$400 \mathrm{mg} / \mathrm{kg}$ body weight) was administered and 20\% mortality was observed in subacute $(400 \mathrm{mg} / \mathrm{kg}$ dose) and chronic toxicity $(200 \mathrm{mg} / \mathrm{kg})$ tests indicating the toxic effect of the plant over long usage [113]. The antifungal and antibacterial $[60,62,114]$, antioxidant $[60,115]$, antimicrobial [116], anthelmintic [117], and uterotonic activity [118] in vitro have been reported (Table 1). Moreover, the lactogenic activity in vivo was investigated and reported in female rats over 400$1600 \mathrm{mg} / \mathrm{kg}$ concentration ranges [119] but despite the various pharmacological effects of the plant in vitro, the antidiabetic activity had been reported.

3.19. Aloe vera. The plant belongs to the Liliaceae family and has its origins in Africa. The plant is commonly called Indian Aloe, True Aloe, Barbados Aloe, Burn Aloe, and so forth [120]. Aloe vera is widely distributed in places such as Arabian Peninsula, Morocco, Mauritania, and Egypt. Traditionally, the plant is used in the treatment of various ailments which includes stimulation of cell growth, restoration of damaged cells, restoration of damaged stomach mucous membrane [121], alleviation of various gastrointestinal tract (GIT) disturbances, haemorrhoid treatment [122], wound healing, thermal burn or sunburn [123], and body immune system stimulation [124]. The anti-inflammatory [125-128], modulatory, antiprotozoal, ultraviolet (UV) protective [128], antimicrobial [121], and antifungal [129] activity in vitro have been reported (Table 1). The wound healing, hypoglycemic, hypolipidemic, and antioxidant activities of the plant in vivo in rabbit and rodents [130-132] have been reported (Table 2).

3.20. Asparagus asparagoides. Asparagus asparagoides is a member of Asparagaceae family. The plant is locally called African Asparagus fern, baby smilax, bridal creeper, and so forth. A. asparagoides is native to SA, Lesotho, and Swaziland and widely distributed in southern Australia and Europe, New Zealand, Hawaii, and California. Traditionally, it is used by Basotho tribe of eastern Free State in the management of $\mathrm{DM}$, though; there has not been any scientific proof for this folkloric use till date. 
3.21. Anthospermum ternatum. The plant is a member of Rubiaceae family. It is widely distributed in Angola, Malawi, Zambia, Zimbabwe, and Tanzania. No scientific report of its antidiabetic activity has been reported to date despite its usage by the Basotho people in the management of DM.

3.22. Erythrina zeyheri. Erythrina zeyheri also belongs to Fabaceae family and Faboideae subfamily. The plant is commonly called harrow-breaker and plough-breaker (Eng.); Ploegbreker (Afr.); Khungoana and Motumo (South Sotho); Umnsinsana (Zulu). The plant grows in grassland and moist vleis with clay soils or sandy soils and it is found in colonies. It is widely spread in Mpumalanga, North West, Gauteng, Free State, KZN, and Lesotho. Traditionally, the plant has its usage in asthma, tuberculosis, rheumatism [133], and DM treatments. The antibacterial $[134,135]$ and anti-inflammatory [133] activity of the plant have been reported, though; scientific evidence on the antidiabetic activity is still awaited.

3.23. Sisymbrium thellungi. Sisymbrium thellungi belongs to the Brassicaceae (Cabbage) family and is commonly called African turnip weep. The plant is native to SA and widely distributed in Northern New South Wales, Queensland, and eastern part of SA. The scientific evidence on antidiabetic potentials of the plant has not been submitted to date.

\section{Conclusion}

Diabetes mellitus (DM) is a major endocrine disorder and its growth or prevalence is attributed to a number of factors that include but are not limited to obesity, social structure, hormonal imbalance, and hereditary. The current trend in the management of DM characterized by hyperglycemia involves the use of herbs since the oral hypoglycemic agents (OHAs) are known to result in unwanted side effects; hence, the need to explore rich and potential plants with antidiabetic activity became necessary. However, from our review, it is evident that the folkloric use of most of these MP has not been adequately explored, thus the need for the government to sponsor or support more research activities in this area so that the potential in these plants to offer lasting solutions to the management of this menace can be ascertained.

\section{Competing Interests}

The authors declare that there is no conflict of interests.

\section{Authors' Contributions}

All authors read and approved the paper for submission.

\section{Acknowledgments}

The authors acknowledge University of the Free State, Qwaqwa campus, research committee for financing the study. The authors also acknowledge Dr. TO Ojuromi and Mr. S. Sabiu for painstakingly reading the paper and making necessary comments and criticism where appropriate.

\section{References}

[1] A. J. Knentz and M. Nattras, "Diabetic ketoacidosis, non ketotic hyperosmolar coma and lactic acidosis," in Handbook of Diabetes, J. C. Pickup and G. Williams, Eds., pp. 479-494, Blackwell Science, 2nd edition, 1991.

[2] P. J. Kumar and M. Clark, Textbook of Clinical Medicine, WB Saunders, London, UK, 2002.

[3] G. B. Kavishankar, N. Lakshmidevi, M. S. Mahadeva et al., "Diabetes and medicinal plants-a review," International Journal of Pharmaceutical and Biomedical Science, vol. 2, no. 3, pp. 65-80, 2011.

[4] D. R. Whiting, L. Guariguata, C. Weil, and J. Shaw, "IDF Diabetes Atlas: global estimates of the prevalence of diabetes for 2011 and 2030," Diabetes Research and Clinical Practice, vol. 94, no. 3, pp. 311-321, 2011.

[5] International Diabetes Federation, "Diabetes at a glance, 2012, Africa (AFR)," http://www.idf.org/sites/default/files/IDF_AFR_ 5E_Update_FactSheet_0.pdf.

[6] A. N. Nagappa, P. A. Thakurdesai, N. V. Rao, and J. Singh, "Antidiabetic activity of Terminalia catappa Linn fruits," Journal of Ethnopharmacology, vol. 88, no. 1, pp. 45-50, 2003.

[7] A. Mohammed, M. A. Ibrahim, and M. D. S. Islam, "African medicinal plants with antidiabetic potentials: a review," Planta Medica, vol. 80, no. 5, pp. 354-377, 2014.

[8] M. P. Kane, A. Abu-Baker, and R. S. Busch, "The utility of oral diabetes medications in type 2 diabetes of the young," Current Diabetes Reviews, vol. 1, no. 1, pp. 83-92, 2005.

[9] G. M. Cragg and D. J. Newman, "Natural products: a continuing source of novel drug leads," Biochimica et Biophysica Acta (BBA)_General Subjects, vol. 1830, no. 6, pp. 3670-3695, 2013.

[10] C. Day, "Traditional plant treatments for diabetes mellitus: pharmaceutical foods," British Journal of Nutrition, vol. 80, no. 1, pp. 5-6, 1998.

[11] X. Zhang, "Legal status of traditional medicines and complementary/alternative medicine: a worldwide review," World Health Organization Technical Report, vol. 2, pp. 5-41, 2001.

[12] B. B. Zhang and D. E. Moller, "New approaches in the treatment of type 2 diabetes," Current Opinion in Chemical Biology, vol. 4, no. 4, pp. 461-467, 2000.

[13] J. B. Calixto, "Efficacy, safety, quality control, marketing and regulatory guidelines for herbal medicines (phytotherapeutic agents)," Brazilian Journal of Medical and Biological Research, vol. 33, no. 2, pp. 179-189, 2000.

[14] B.-E. van Wyk, "A review of Khoi-San and Cape Dutch medical ethnobotany," Journal of Ethnopharmacology, vol. 119, no. 3, pp. 331-341, 2008.

[15] K. L. Wilson, An Investigation Into the Antibacterial Activity of Medicinal Plants Traditionally Used in the Eastern Cape to Treat Lung Infections in Cystic Fibrosis Patients, Faculty of Applied Science, Port Elizabeth, South Africa, 2004.

[16] N. D. Nielsen, M. Sandager, G. I. Stafford, J. Van Staden, and A. K. Jäger, "Screening of indigenous plants from South Africa for affinity to the serotonin reuptake transport protein," Journal of Ethnopharmacology, vol. 94, no. 1, pp. 159-163, 2004.

[17] A. Dyson, Discovering Indigenous Healing Plants of the Herb and Fragrance Gardens at Kirstenbosch National Botanical Garden, NBI, Cape Town, South Africa, 1998.

[18] M. Bnouham, H. Mekhfi, A. Legssyer, and A. Ziyyat, "Medicinal plants used in the treatment of diabetes in Morocco," International Journal of Diabetes and Metabolism, vol. 10, no. 1, pp. 3350, 2002. 
[19] M. Eddouks, M. Maghrani, A. Lemhadri, M.-L. Ouahidi, and H. Jouad, "Ethnopharmacological survey of medicinal plants used for the treatment of diabetes mellitus, hypertension and cardiac diseases in the south-east region of Morocco (Tafilalet)," Journal of Ethnopharmacology, vol. 82, no. 2-3, pp. 97-103, 2002.

[20] T. M. Mahop and M. Mayet, "Enroute to biopiracy? Ethnobotanical research on antidiabetic medicinal plants in the Eastern Cape Province, South Africa," African Journal of Biotechnology, vol. 6, pp. 2945-2952, 2007.

[21] A. A. Gbolade, "Inventory of antidiabetic plants in selected districts of Lagos State, Nigeria," Journal of Ethnopharmacology, vol. 121, no. 1, pp. 135-139, 2009.

[22] K. N’guessa, K. Kouassi, and K. Kouadio, "Ethnobotanical study of plants used to treat diabetes in traditional medicine, by Abbey and Krobou people of Agboville, Côte-d'Ivoire," American Journal of Science Research, vol. 4, pp. 45-58, 2009.

[23] A. J. Afolayan and T. O. Sunmonu, "In vivo studies on antidiabetic plants used in South African herbal medicine," Journal of Clinical Biochemistry and Nutrition, vol. 47, no. 2, pp. 98-106, 2010.

[24] N. Din, S. D. Dibong, E. Mpondo Mpondo, R. J. Priso, N. F. Kwin, and A. Ngoye, "Inventory and identification of plants used in the treatment of diabetes in Douala Town (Cameroon)," European Journal of Medicinal Plants, vol. 1, no. 3, pp. 60-73, 2011.

[25] L. K. Keter and P. C. Mutiso, "Ethnobotanical studies of medicinal plants used by traditional health practitioners in the management of diabetes in lower Eastern Province, Kenya," Journal of Ethnopharmacology, vol. 139, no. 1, pp. 74-80, 2012.

[26] A. Rachid, D. Rabah, L. Farid et al., "Ethnopharmacological survey of medicinal plants used in the traditional treatment of diabetes mellitus in the North Western and South Western Algeria," Journal of Medicinal Plants Research, vol. 6, no. 10, pp. 2041-2050, 2012.

[27] E. Rutebemberwa, M. Lubega, S. K. Katureebe, A. Oundo, F. Kiweewa, and D. Mukanga, "Use of traditional medicine for the treatment of diabetes in Eastern Uganda: a qualitative exploration of reasons for choice," BMC International Health and Human Rights, vol. 13, article 1, 2013.

[28] N. T. Tshabalala and A. O. T. Ashafa, Ethnobotanical survey of Sotho medicinal plants used in the management of diabetes in the eastern Free State, South Africa [Honours dissertation], Department of Plant Sciences, University of the Free State, Qwaqwa, South Africa, 2011.

[29] H.-G. Mierendorff, E. Stahl-Biskup, M. A. Posthumus, and T. A. van Beek, "Composition of commercial cape chamomile oil (Eriocephalus punctulatus)," Flavour and Fragrance Journal, vol. 18, no. 6, pp. 510-514, 2003.

[30] A. Shuttleworth and S. D. Johnson, "Specialized pollination in the African milkweed Xysmalobium orbiculare: a key role for floral scent in the attraction of spider-hunting wasps," Plant Systematics and Evolution, vol. 280, no. 1-2, pp. 37-44, 2009.

[31] J. M. Watt and M. G. Breyer-Brandwijk, Medicinal and Poisonous Plants of Southern and Eastern Africa, E \& S Livingstone, Edinburgh, UK, 2nd edition, 1962.

[32] B.-E. Van Wyk, H. de Wet, and F. R. Van Heerden, "An ethnobotanical survey of medicinal plants in the southeastern Karoo, South Africa," South African Journal of Botany, vol. 74, no. 4, pp. 696-704, 2008.

[33] M. Sandasi, G. P. P. Kamatou, and A. M. Viljoen, "Chemotaxonomic evidence suggests that Eriocephalus tenuifolius is the source of Cape chamomile oil and not Eriocephalus punctulatus," Biochemical Systematics and Ecology, vol. 39, no. 4-6, pp. 328-338, 2011.

[34] E. W. Njenga, S. F. Van Vuuren, and A. M. Viljoen, "Antimicrobial activity of Eriocephalus L. species," South African Journal of Botany, vol. 71, no. 1, pp. 81-87, 2005.

[35] E. W. Njenga and A. M. Viljoen, "In vitro 5-lipoxygenase inhibition and anti-oxidant activity of Eriocephalus L. (Asteraceae) species," South African Journal of Botany, vol. 72, no. 4, pp. 637641, 2006.

[36] O. Laporta, L. Funes, M. T. Garzón, J. Villalaín, and V. Micol, "Role of membranes on the antibacterial and anti-inflammatory activities of the bioactive compounds from Hypoxis rooperi corm extract," Archives of Biochemistry and Biophysics, vol. 467, no. 1, pp. 119-131, 2007.

[37] J. A. O. Ojewole, "Antinociceptive, anti-inflammatory and antidiabetic properties of Hypoxis hemerocallidea Fisch. \& C.A. Mey. (Hypoxidaceae) corm ['African Potato'] aqueous extract in mice and rats," Journal of Ethnopharmacology, vol. 103, no. 1, pp. 126-134, 2006.

[38] J. Ojewole, D. R. Kamadyaapa, and C. T. Musabayane, "Some in vitro and in vivo cardiovascular effects of Hypoxis hemerocallidea Fisch \& CA Mey (Hypoxidaceae) corm (African potato) aqueous extract in experimental animal models," Cardiovascular Journal of South Africa, vol. 17, no. 4, pp. 166-171, 2006.

[39] P. J. D. Bouic, S. Etsebeth, R. W. Liebenberg, C. F. Albrecht, K. Pegel, and P. P. Van Jaarsveld, "Beta-sitosterol and betasitosterol glucoside stimulate human peripheral blood lymphocyte proliferation: implications for their use as an immunomodulatory vitamin combination," International Journal of Immunopharmacology, vol. 18, no. 12, pp. 693-700, 1996.

[40] S. E. Drewes and S. F. van Vuuren, "Antimicrobial acylphloroglucinols and dibenzyloxy flavonoids from flowers of $\mathrm{Hel}$ ichrysum gymnocomum," Phytochemistry, vol. 69, no. 8, pp. 1745-1749, 2008.

[41] D. R. Katerere and J. N. Eloff, "Anti-bacterial and anti-oxidant activity of Hypoxis hemerocallidea (Hypoxidaceae): can leaves be substituted for corms as a conservation strategy?" South African Journal of Botany, vol. 74, no. 4, pp. 613-616, 2008.

[42] Z. Liu, J. H. Wilson-Welder, J. M. Hostetter, A. E. Jergens, and M. J. Wannemuehler, "Prophylactic treatment with Hypoxis hemerocallidea corm (African potato) methanolic extract ameliorates Brachyspira hyodysenteriae-induced murine typhlocolitis," Experimental Biology and Medicine, vol. 235, no. 2, pp. 222-229, 2010.

[43] J. A. O. Ojewole, G. Olayiwola, and A. Nyinawumuntu, "Bronchorelaxant property of "African potato" (Hypoxis hemerocallidea corm) aqueous extract in vitro," Journal of Smooth Muscle Research, vol. 45, no. 5, pp. 241-248, 2009.

[44] A. Nyinawumuntu, E. O. Awe, and J. A. O. Ojewole, "Uterolytic effect of Hypoxis hemerocallidea Fisch. \& C.A. Mey. (Hypoxidaceae) corm ['African Potato'] aqueous extract," Journal of Smooth Muscle Research, vol. 44, no. 5, pp. 167-176, 2008.

[45] S. M. X. Zibula and J. A. O. Ojewole, "Hypoglycaemic effects of Hypoxis hemerocallidea corm 'African Potato' methanolic extract in rats," Medical Journal of Islamic and Academic Science, vol. 13, pp. 75-78, 2000.

[46] I. M. Mahomed and J. A. O. Ojewole, "Hypoglycemic effect of Hypoxis hemerocallidea corm 'African potato' aqueous extract in rats," Methods and Findings in Experimental and Clinical Pharmacology, vol. 25, no. 8, pp. 617-623, 2003. 
[47] V. Steenkamp, M. C. Gouws, M. Gulumian, E. E. Elgorashi, and J. Van Staden, "Studies on antibacterial, anti-inflammatory and antioxidant activity of herbal remedies used in the treatment of benign prostatic hyperplasia and prostatitis," Journal of Ethnopharmacology, vol. 103, no. 1, pp. 71-75, 2006.

[48] B. E. van Wyk, B. van Oudtshoorn, and N. Gericke, Medicinal Plants of South Africa, Briza Publications Pretoria, 1997.

[49] M. M. van der Merwe, Bioactive sesquiterpenoids from Dicoma anomala subsp. Gerradii [M.S. thesis], University of KwaZuluNatal (UKZN), School of Chemistry, Durban, South Africa, 2008.

[50] M. Gelfand, S. Mavi, R. B. Drummond, and B. Ndemera, The Traditional Medical Practitioner in Zimbabwe: His Principles of Practice and Pharmacopoeia, Mambo Press, Gweru, Zimbabwe, 1985.

[51] M. Roberts, Indigenous Healing Plants, Southern Book, Pretoria, South Africa, 1990.

[52] E. von Koenen, Medicinal, Poisonous and Edible Plants in Namibia, Klaus Hess, Windhoek, Namibia, 2001.

[53] O. Jansen, M. Tits, L. Angenot et al., "Anti-plasmodial activity of Dicoma tomentosa (Asteraceae) and identification of urospermal A-15-O-acetate as the main active compound," Malaria Journal, vol. 11, article 289, 2012.

[54] L. Gwaza, A. R. Wolfe, L. Z. Benet et al., "In vitro inhibitory effects of Hypoxis obtuse and Dicoma anomala on cyp450 enzymes and glycoproteins," African Journal of Pharmacy and Pharmacology, vol. 3, no. 11, pp. 539-546, 2009.

[55] J. V. Becker, M. M. van der Merwe, A. C. van Brummelen et al., "In vitro anti-plasmodial activity of Dicoma anomala subsp. gerrardii (Asteraceae): Identification of its main active constituent, structure-activity relationship studies and gene expression profiling," Malaria Journal, vol. 10, article 295, 2011.

[56] F. Balogun and A. Ashafa, "Comparative study on the antioxidant activity of Dicoma anomala and Gazania krebsiana used in Basotho traditional medicine," South African Journal of Botany, vol. 98, p. 170, 2015.

[57] A. Hutchings and J. van Staden, "Plants used for stress-related ailments in traditional Zulu, Xhosa and Sotho medicine. Part 1: plants used for headaches," Journal of Ethnopharmacology, vol. 43, no. 2, pp. 89-124, 1994.

[58] A. Hutchings, A. H. Scott, G. Lewis, and A. B. Cunningham, Zulu Medicinal Plants: An Inventory, University of Natal Press, Pietermaritzburg, South Africa, 1996.

[59] M. Ghorbani, M. Kaloga, H.-H. Frey, G. Mayer, and E. Eich, "Phytochemical reinvestigation of Xysmalobium undulatum roots (Uzara)," Planta Medica, vol. 63, no. 4, pp. 343-346, 1997.

[60] V. Steenkamp, E. Mathivha, M. C. Gouws, and C. E. J. Van Rensburg, "Studies on antibacterial, antioxidant and fibroblast growth stimulation of wound healing remedies from South Africa," Journal of Ethnopharmacology, vol. 95, no. 2-3, pp. 353357, 2004.

[61] M. E. Pedersen, A. Weng, A. Sert A et al., "Pharmacological Studies on Xysmalobium undulatum and Mondia whitei-two South African plants with in vitro SSRI activity," Planta Medica, vol. 72, article 123, 2006.

[62] L. V. Buwa and J. van Staden, "Antibacterial and antifungal activity of traditional medicinal plants used against venereal diseases in South Africa," Journal of Ethnopharmacology, vol. 103, no. 1, pp. 139-142, 2006.

[63] G. I. Stafford, A. K. Jäger, and J. van Staden, "Effect of storage on the chemical composition and biological activity of several popular South African medicinal plants," Journal of Ethnopharmacology, vol. 97, no. 1, pp. 107-115, 2005.

[64] I. Vermaak, G. M. Enslin, T. O. Idowu, and A. M. Viljoen, "Xysmalobium undulatum (uzara)-review of an antidiarrhoeal traditional medicine," Journal of Ethnopharmacology, vol. 156, pp. 135-146, 2014.

[65] L. Seleteng Kose, A. Moteetee, and S. van Vuuren, "Ethnobotanical survey of medicinal plants used in the Maseru district of Lesotho," Journal of Ethnopharmacology, vol. 170, pp. 184-200, 2015.

[66] A. O. T. Ashafa, "Medicinal potential of Morella serata (Lam.) Killick (Myricaceae) root extracts: biological and pharmacological activities," BMC Complementary and Alternative Medicine, vol. 13, article 163, 2013.

[67] A. Hutchings, "A survey and analysis of traditional medicinal plants as used by the Zulu, Xhosa and Sotho," Bothalia, vol. 19, no. 1, pp. 111-123, 1989.

[68] J. Pujol, Naturafrica-the Herbalist Handbook, Jean Pujol Natural Healers Foundation, Durban, South Africa, 1990.

[69] A. P. Dold and M. L. Cocks, "Traditional veterinary medicine in the Alice district of the Eastern Cape Province, South Africa," South African Journal of Science, vol. 97, no. 9-10, pp. 375-379, 2001.

[70] L. J. Mcgaw and J. N. Eloff, "Ethnoveterinary use of southern African plants and scientific evaluation of their medicinal properties," Journal of Ethnopharmacology, vol. 119, no. 3, pp. 559-574, 2008.

[71] V. Maphosa, P. J. Masika, E. S. Bizimenyera, and J. N. Eloff, “Invitro anthelminthic activity of crude aqueous extracts of Aloe ferox, Leonotis leonurus and Elephantorrhiza elephantina against Haemonchus contortus," Tropical Animal Health and Production, vol. 42, no. 2, pp. 301-307, 2010.

[72] C. Kamaraj, A. A. Rahuman, G. Elango, A. Bagavan, and A. A. Zahir, "Anthelmintic activity of botanical extracts against sheep gastrointestinal nematodes, Haemonchus contortus," Parasitology Research, vol. 109, no. 1, pp. 37-45, 2011.

[73] V. Maphosa and P. J. Masika, "In vivo validation of Aloe ferox (Mill). Elephantorrhiza elephantina Bruch. Skeels. and Leonotis leonurus (L) R. BR as potential anthelminthics and antiprotozoals against mixed infections of gastrointestinal nematodes in goats," Parasitology Research, vol. 110, no. 1, pp. 103-108, 2012.

[74] M. C. Mathabe, R. V. Nikolova, N. Lall, and N. Z. Nyazema, "Antibacterial activities of medicinal plants used for the treatment of diarrhoea in Limpopo Province, South Africa," Journal of Ethnopharmacology, vol. 105, no. 1-2, pp. 286-293, 2006.

[75] V. Maphosa, P. J. Masika, and B. Moyo, "Investigation of the antiinflammatory and antinociceptive activities of Elephantorrhiza elephantina (Burch.) Skeels root extract in male rats," African Journal of Biotechnology, vol. 8, no. 24, pp. 7068-7072, 2009.

[76] U. Mabona, A. Viljoen, E. Shikanga, A. Marston, and S. Van Vuuren, "Antimicrobial activity of southern African medicinal plants with dermatological relevance: from an ethnopharmacological screening approach, to combination studies and the isolation of a bioactive compound," Journal of Ethnopharmacology, vol. 148, no. 1, pp. 45-55, 2013.

[77] S. J. Mpofu, T. A. M. Msagati, and R. W. M. Krause, "Cytotoxicity, phytochemical analysis and antioxidant activity of crude extracts from rhizomes of Elephantorrhiza elephantina and Pentanisia prunelloides," African Journal of Traditional, Complementary, and Alternative Medicines, vol. 11, no. 1, pp. 3452, 2014. 
[78] B. Mnandi, Evaluation of botanical extracts with immune enhancing and /or anti-HIV activity in vitro [M.S. thesis], University of Johannesburg Institutional Repository and Scholarly Communication, 2002, http://hdl.handle.net/10210/3945.

[79] W. G. Wright, The Wild Flowers of Southern Africa, Natal Nelson, Cape Town, South Africa, 1963.

[80] R. N. Bolofo and C. T. Johnson, "The identification of 'Isicakathi' and its medicinal use in Transkei," Bothalia, vol. 18, no. 1, pp. 125-130, 1988.

[81] O. S. Agunbiade, O. M. Ojezele, J. O. Ojezele, and A. Y. Ajayi, "Hypoglycaemic activity of Commelina africana and Ageratum conyzoides in relation to their mineral composition," African Health Sciences, vol. 12, no. 2, pp. 198-203, 2012.

[82] E. Pooley, A Field Guide to Wild Flowers of KwaZulu-Natal and the Eastern Region, Natal Flora Publications Trust, Durban, South Africa, 1998.

[83] T. L. Shale, W. A. Stirk, and J. van Staden, "Screening of medicinal plants used in Lesotho for anti-bacterial and antiinflammatory activity," Journal of Ethnopharmacology, vol. 67, no. 3, pp. 347-354, 1999.

[84] Flora of Zimbabwe, Helichrysum aureum (Houtt.) Merr, 2011, http://www.zimbabweflora.co.zw/speciesdata/species.php?species_id=159490.

[85] A. C. U. Lourens, A. M. Viljoen, and F. R. van Heerden, "South African Helichrysum species: a review of the traditional uses, biological activity and phytochemistry," Journal of Ethnopharmacology, vol. 119, no. 3, pp. 630-652, 2008.

[86] A. C. U. Lourens, S. F. van Vuuren, A. M. Viljoen, H. Davids, and F. R. Van Heerden, "Antimicrobial activity and in vitro cytotoxicity of selected South African Helichrysum species," South African Journal of Botany, vol. 77, no. 1, pp. 229-235, 2011.

[87] Y. Frum and A. M. Viljoen, "In vitro 5-lipoxygenase and antioxidant activities of South African medicinal plants commonly used topically for skin diseases," Skin Pharmacology and Physiology, vol. 19, no. 6, pp. 329-335, 2006.

[88] B. T. S. Yff, K. L. Lindsey, M. B. Taylor, D. G. Erasmus, and A. K. Jäger, "The pharmacological screening of Pentanisia prunelloides and the isolation of the antibacterial compound palmitic acid," Journal of Ethnopharmacology, vol. 79, no. 1, pp. 101-107, 2002.

[89] B. Madikizela, A. R. Ndhlala, J. F. Finnie, and J. V. Staden, "In vitro antimicrobial activity of extracts from plants used traditionally in South Africa to treat tuberculosis and related symptoms," Evidence-Based Complementary and Alternative Medicine, vol. 2013, Article ID 840719, 8 pages, 2013.

[90] B. Madikizela, A. R. Ndhlala, J. F. Finnie, and J. van Staden, "Antimycobacterial, anti-inflammatory and genotoxicity evaluation of plants used for the treatment of tuberculosis and related symptoms in South Africa," Journal of Ethnopharmacology, vol. 153, no. 2, pp. 386-391, 2014.

[91] E. Muleya, A. S. Ahmed, A. M. Sipamla, F. M. Mtunzi, and W. Mutatu, "Pharmacological properties of Pomaria sandersonii, Pentanisia prunelloides and Alepidea amatymbica extracts using in vitro assays," Journal of Pharmacognosy and Phytotherapy, vol. 7, no. 1, pp. 1-8, 2015.

[92] S. L. Datwyler and G. D. Weiblen, "Genetic variation in hemp and marijuana (Cannabis sativa L.) according to amplified fragment length polymorphisms," Journal of Forensic Sciences, vol. 51, no. 2, pp. 371-375, 2006.

[93] B. E. van Wyk, B. van Oudtshoom, and N. Gericke, Medicinal Plants of South Africa, Briza Publication, Pretoria, South Africa, 2nd edition, 2000.
[94] B. R. Martin, R. Mechoulam, and R. K. Razdan, "Discovery and characterization of endogenous cannabinoids," Life Sciences, vol. 65 , no. 6-7, pp. 573-595, 1999.

[95] A. W. Zuardi, J. A. S. Crippa, J. E. C. Hallak, F. A. Moreira, and F. S. Guimarães, "Cannabidiol, a Cannabis sativa constituent, as an antipsychotic drug," Brazilian Journal of Medical and Biological Research, vol. 39, no. 4, pp. 421-429, 2006.

[96] A. W. Zuardi, E. Finkelfarb, O. F. A. Bueno, R. E. Musty, and I. G. Karniol, "Characteristics of the stimulus produced by the mixture of cannabidiol with $\Delta 9$-tetrahydrocannabinol," Archives of International Pharmacodynamics Therapy, vol. 249, no. 1, pp. 137-146, 1981.

[97] F. A. Moreira and F. S. Guimarães, "Cannabidiol inhibits the hyperlocomotion induced by psychotomimetic drugs in mice," European Journal of Pharmacology, vol. 512, no. 2-3, pp. 199-205, 2005.

[98] T. Iuvone, G. Esposito, R. Esposito, R. Santamaria, M. Di Rosa, and A. A. Izzo, "Neuroprotective effect of cannabidiol, a nonpsychoactive component from Cannabis sativa, on $\beta$-amyloidinduced toxicity in PC12 cells," Journal of Neurochemistry, vol. 89, no. 1, pp. 134-141, 2004.

[99] G. Appendino, S. Gibbons, A. Giana et al., "Antibacterial cannabinoids from Cannabis sativa: a structure-activity study," Journal of Natural Products, vol. 71, no. 8, pp. 1427-1430, 2008.

[100] Y. Gaoni and R. Mechoulam, "Isolation, structure, and partial synthesis of an active constituent of hashish," Journal of the American Chemical Society, vol. 86, no. 8, pp. 1646-1647, 1964.

[101] E. A. Carlini, "The good and the bad effects of (-) trans-delta-9tetrahydrocannabinol $\left(\Delta^{9}\right.$-THC) on humans," Toxicon, vol. 44, no. 4, pp. 461-467, 2004.

[102] L. M. Eubanks, C. J. Rogers, A. E. Beuscher IV et al., "A molecular link between the active component of marijuana and Alzheimer's disease pathology," Molecular Pharmaceutics, vol. 3, no. 6, pp. 773-777, 2006.

[103] A. J. Guillamord, Flora of Lesotho (Basotho land), Lubrecht \& Cramer, Port Jervis, NY, USA, 1971.

[104] R. M. Coopoosamy, "Traditional information and antibacterial activity of four Bulbine species (Wolf)," African Journal of Biotechnology, vol. 10, no. 2, pp. 220-224, 2011.

[105] C. Mocktar, Antimicrobial and chemical analyses of selected Bulbine species [M.S. dissertation], University of Durban, Westville, Durban, South Africa, 2000.

[106] B. van Wyk and P. van Wyk, Field Guide to Trees of Southern Africa, Struik, Cape Town, South Africa, 1997.

[107] A. Hutchings, Zulu Medicinal Plants, University of Natal Press, Pietermaritzburg, South Africa, 1996.

[108] A. Nair, An investigation into the potential mutagenicity of South African traditional medicinal plants [M.S. thesis], University of Cape Town, 2010.

[109] B. Bergman, C. Johansson, and E. Soderback, "The NostocGunnera symbiosis," New Phytologist, vol. 122, no. 3, pp. 379400, 1992.

[110] B. E. van Wyk and N. Gericke, People's Plants: A Guide to Useful Plants of Southern Africa, Briza Publication, Pretoria, South Africa, 2000.

[111] A. Ngwenya, A. Koopman, and R. Williams, Zulu Botanical Knowledge: An Introduction, National Botanical Institute, Durban, South Africa, 2003.

[112] D. von Ahlenfeldt, N. R. Crouch, G. Nichols et al., Medicinal Plants Traded on South Africa's Eastern Seaboard, Ethekweni Parks, Department and University of Natal, Durban, South Africa, 2003. 
[113] M. Mwale and P. J. Masika, "Toxicity evaluation of the aqueous leaf extract of Gunnera perpensa L. (Gunneraceae)," African Journal of Biotechnology, vol. 10, no. 13, pp. 2503-2513, 2011.

[114] S. E. Drewes, F. Khan, S. F. van Vuuren, and A. M. Viljoen, "Simple 1, 4-benzoquinones with antibacterial activity from stems and leaves of Gunnera perpensa," Phytochemistry, vol. 66, no. 15, pp. 1812-1816, 2005.

[115] M. B. C. Simelane, O. A. Lawal, T. G. Djarova, and A. R. Opoku, "In vitro antioxidant and cytotoxic activity of Gunnera perpensa L. (Gunneraceae) from South Africa," Journal of Medicinal Plants Research, vol. 4, no. 21, pp. 2181-2188, 2010.

[116] M. Nkomo and L. Kambizi, "Antimicrobial activity of Gunnera perpensa and Heteromorpha arborescens var. abyssinica," Journal of Medicinal Plant Research, vol. 3, pp. 1051-1055, 2009.

[117] L. J. McGaw, A. K. Jäger, and J. Van Staden, "Antibacterial, anthelmintic and anti-amoebic activity in South African medicinal plants," Journal of Ethnopharmacology, vol. 72, no. 1-2, pp. 247-263, 2000.

[118] L. J. McGaw, R. Gehring, L. Katsoulis, and J. N. Eloff, "Is the use of Gunnera perpensa extracts in endometritis related to antibacterial activity? Onderstepoort," Journal of Veterinary Research, vol. 72, no. 2, pp. 129-134, 2005.

[119] M. B. C. Simelane, O. A. Lawal, T. G. Djarova, C. T. Musabayane, M. Singh, and A. R. Opoku, "Lactogenic activity of rats stimulated by Gunnera perpensa L. (Gunneraceae) from South Africa," African Journal of Traditional, Complementary and Alternative Medicines, vol. 9, no. 4, pp. 561-573, 2012.

[120] Z. Liao, M. Chen, F. Tan, X. Sun, and K. Tang, "Microprogagation of endangered Chinese Aloe," Plant Cell, Tissue and Organ Culture, vol. 76, no. 1, pp. 83-86, 2004.

[121] O. O. Agarry, M. T. Olaleye, and C. O. Bello-Michael, "Comparative antimicrobial activities of Aloe vera gel and leaf," African Journal of Biotechnology, vol. 4, no. 12, pp. 1413-1414, 2005.

[122] A. O. T. Ashafa, T. O. Sunmonu, A. A. Abass, and A. A. Ogbe, "Laxative potential of the ethanolic leaf extract of Aloe vera (L.) Burm. f. in Wistar rats with loperamide-induced constipation," Journal of Natural Pharmaceuticals, vol. 2, no. 3, pp. 158-162, 2011.

[123] S. Foster, "Aloe vera: the succulent with skin soothing cell protecting properties," in Herbs for Health Magazine, Health World Online, 1999.

[124] H. R. Davis, Aloe vera: A Scientific Approach, Vantage Press, New York, NY, USA, 1997.

[125] R. H. Davis, J. J. Donato, G. M. Hartman, and R. C. Haas, "Anti-inflammatory and wound healing activity of a growth substance in Aloe vera," Journal of the American Podiatric Medical Association, vol. 84, no. 2, pp. 77-81, 1994.

[126] B. Vázquez, G. Avila, D. Segura, and B. Escalante, "Antiinflammatory activity of extracts from Aloe vera gel," Journal of Ethnopharmacology, vol. 55, no. 1, pp. 69-75, 1996.

[127] S. Choi and M.-H. Chung, "A review on the relationship between Aloe vera components and their biologic effects," Seminars in Integrative Medicine, vol. 1, no. 1, pp. 53-62, 2003.

[128] L. Langmead, R. M. Feakins, S. Goldthorpe et al., "Randomized, double-blind, placebo-controlled trial of oral aloe vera gel for active ulcerative colitis," Alimentary Pharmacology and Therapeutics, vol. 19, no. 7, pp. 739-747, 2004.

[129] O. Rosca-Casian, M. Parvu, L. Vlase, and M. Tamas, "Antifungal activity of Aloe vera leaves," Fitoterapia, vol. 78, no. 3, pp. 219222, 2007.
[130] P. Chithra, G. B. Sajithlal, and G. Chandrakasan, "Influence of Aloe vera on the glycosaminoglycans in the matrix of healing dermal wounds in rats," Journal of Ethnopharmacology, vol. 59, no. 3, pp. 179-186, 1998.

[131] K. Kim, H. Kim, J. Kwon et al., "Hypoglycemic and hypolipidemic effects of processed Aloe vera gel in a mouse model of non-insulin-dependent diabetes mellitus," Phytomedicine, vol. 16, no. 9, pp. 856-863, 2009.

[132] S. Rajasekaran, K. Sivagnanam, and S. Subramanian, "Antioxidant effect of Aloe vera gel extract in streptozotocin-induced diabetes in rats," Pharmacological Reports, vol. 57, no. 1, pp. 9096, 2005.

[133] C. C. N. Pillay, A. K. Jäger, D. A. Mulholland, and J. Van Staden, "Cyclooxygenase inhibiting and anti-bacterial activities of South African Erythrina species," Journal of Ethnopharmacology, vol. 74, no. 3, pp. 231-237, 2001.

[134] H. Tanaka, T. Oh-Uchi, H. Etoh et al., "Isoflavonoids from roots of Erythrina zeyheri," Phytochemistry, vol. 64, no. 3, pp. 753-758, 2003.

[135] M. Sato, H. Tanaka, T. Oh-Uchi, T. Fukai, H. Etof, and M. Yamaguchi, "Antibacterial activity of phytochemicals isolated from Erythrina zeyheri against vancomycin-resistant enterococci and their combinations with vancomycin," Phytotherapy Research, vol. 18, no. 11, pp. 906-910, 2004.

[136] S. Rajasekaran, K. Ravi, K. Sivagnanam, and S. Subramanian, "Beneficial effects of Aloe vera leaf gel extract on lipid profile status in rats with streptozotocin diabetes," Clinical and Experimental Pharmacology and Physiology, vol. 33, no. 3, pp. 232-237, 2006.

[137] Y. Y. Pérez, E. Jiménez-Ferrer, A. Zamilpa et al., "Effect of a polyphenol-rich extract from Aloe vera gel on experimentally induced insulin resistance in mice," The American Journal of Chinese Medicine, vol. 35, no. 6, pp. 1037-1046, 2007.

[138] M. Choudhary, A. Kochhar, and J. Sangha, "Hypoglycemic and hypolipidemic effect of Aloe vera L. in non-insulin dependent diabetics," Journal of Food Science and Technology, vol. 51, no. 1, pp. 90-96, 2014. 


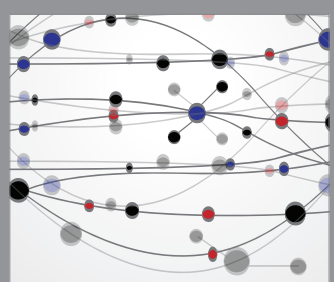

The Scientific World Journal
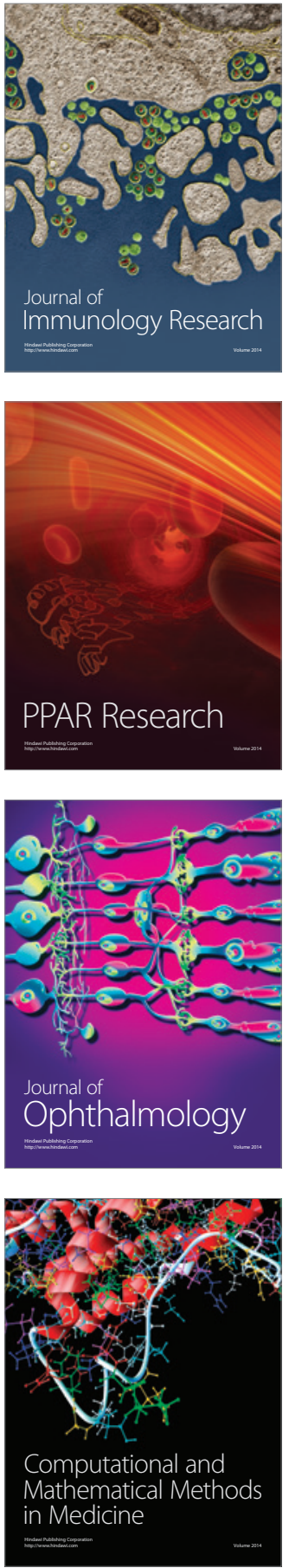

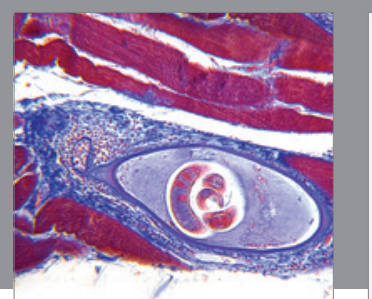

Gastroenterology Research and Practice

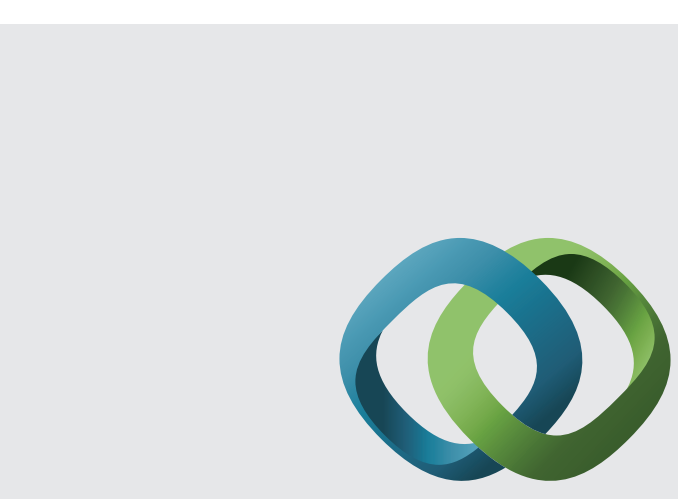

\section{Hindawi}

Submit your manuscripts at

http://www.hindawi.com
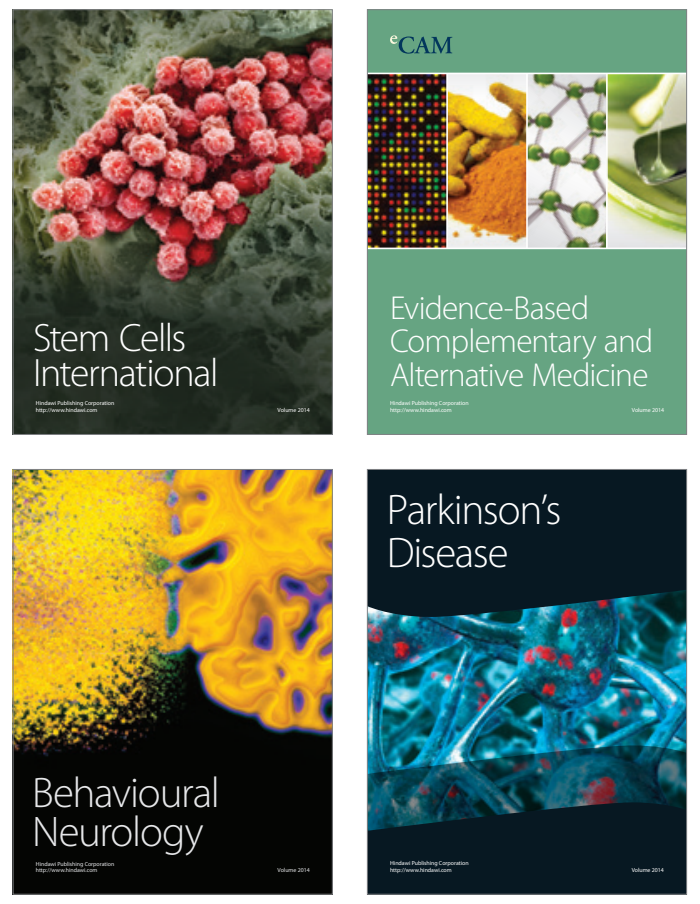
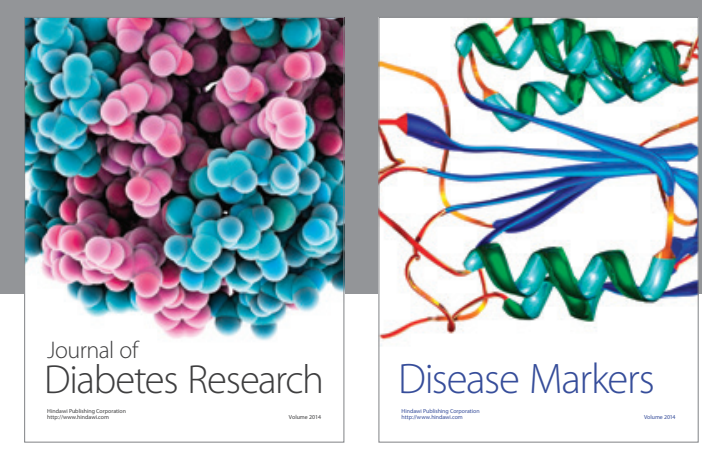

Disease Markers
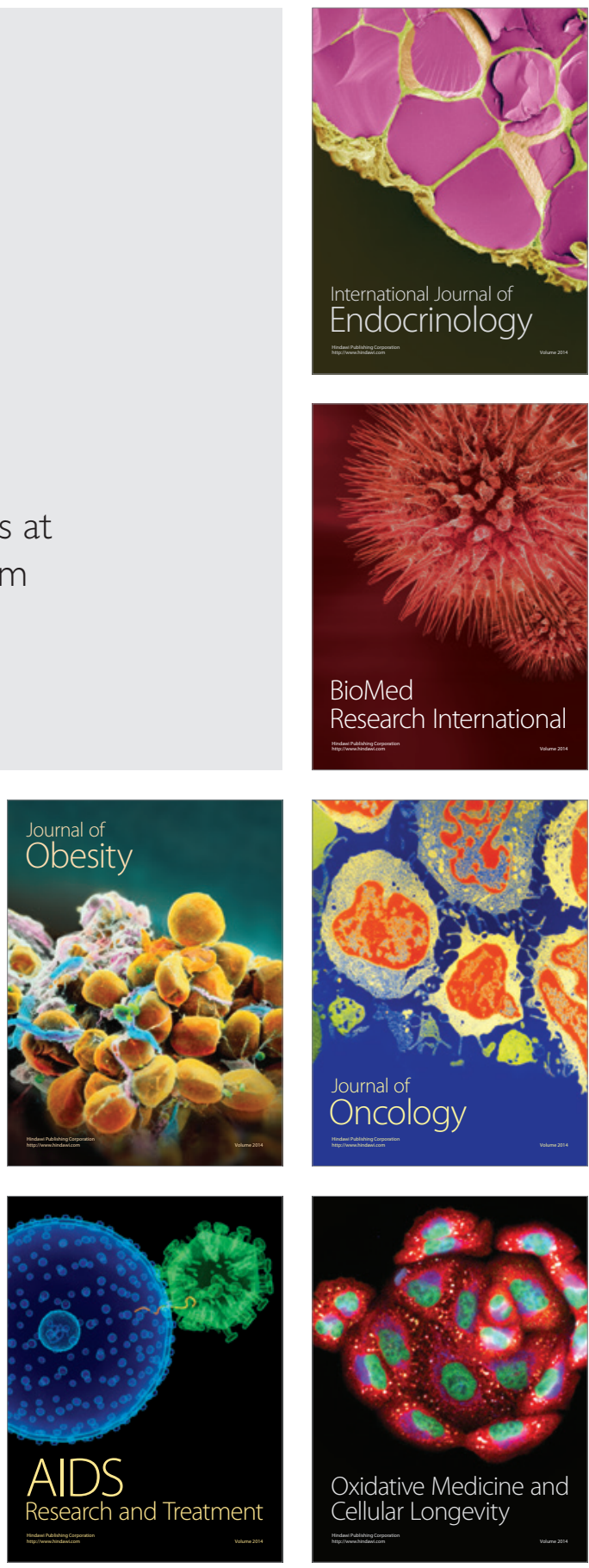